\title{
STUDI KOMPARASI MODEL PEMBELAJARAN THINKING ALOUD PAIR PROBLEM SOLVING (TAPPS) DAN DOUBLE LOOP PROBLEM SOLVING (DLPS) DITINJAU DARI KEMAMPUAN MATEMATIK TERHADAP PRESTASI BELAJAR SISWA MATERI LARUTAN PENYANGGA KELAS XI IPA SMA NEGERI KEBAKKRAMAT
}

\author{
Eko Safitri ${ }^{*}$ Endang Susilowati, dan Sulistyo Saputro \\ Program Studi Pendidikan Kimia, FKIP, Universitas Sebelas Maret, Surakarta, Indonesia \\ *Keperluan korespondensi, tel/fax: 089697778632, email: ekosafitri12@gmail.com
}

\begin{abstract}
ABSTRAK
Penelitian ini merupakan penelitian eksperimental dengan desain faktorial $2 \times 2$. Populasi dalam penelitian ini adalah seluruh siswa kelas XI IPA SMA Negeri Kebakkramat tahun pelajaran 2017/2018. Sampel penelitian terdiri dari 2 kelas yaitu XI IPA 1 dan XI IPA 3 yang diperoleh dengan menggunakan teknik cluster random sampling. Kelas XI IPA 1 diberikan model pembelajaran TAPPS dan XI IPA 3 diberikan model pembelajaran DLPS. Uji hipotesis pada penelitian ini menggunakan uji statistic non parametrik Kruskal Wallis. Penelitian ini mempunyai tujuan untuk mengetahui: (1) perbedaan penggunaan model pembelajaran Thinking Aloud Pair Problem Solving (TAPPS) dan Double Loop Problem Solving (DLPS) pada materi larutan penyangga terhadap prestasi belajar siswa, (2) perbedaan kemampuan matematik yang tinggi dan yang rendah terhadap prestasi belajar siswa, (3) interaksi antara model pembelajaran Thinking Aloud Pair Problem Solving (TAPPS) dan Double Loop Problem Solving (DLPS) dengan kemampuan matematik terhadap prestasi belajar siswa pada materi larutan penyangga. Dilihat dari hasil penelitian yang telah dilakukan, kesimpulan yang diperoleh yaitu: (1) prestasi belajar ranah kognitif menunjukkan rerata model pembelajaran TAPPS lebih baik daripada model pembelajaran DLPS, namun tidak ada perbedaan prestasi belajar ranah afektif dan psikomotorik terhadap model pembelajaran, (2) siswa dengan kemampuan matematika tinggi mempunyai prestasi belajar kognitif yang lebih baik daripada siswa dengan kemampuan matematik rendah namun tidak ada perbedaan terhadap prestasi belajar ranah afektif dan psikomotorik, (3) terdapat interaksi antara model pembelajaran TAPPS dan DLPS dengan kemampuan matematik terhadap prestasi belajar ranah kognitif, namun tidak ada interaksi pada ranah afektif dan psikomotorik.
\end{abstract}

Kata Kunci: Model TAPPS, Model DLPS, Kemampuan Matematik, Prestasi Belajar, Larutan Penyangga.

\section{PENDAHULUAN}

Indonesia merupakan salah satu negara berkembang dengan jumlah penduduk yang cukup banyak serta sumber daya alam yang melimpah namun tergolong masih tertinggal dengan negara lain. Salah satu faktor yang menyebabkan hal tersebut terjadi adalah masih rendahnya mutu pendidikan yang ada di Indonesia. Padahal pendidikan merupakan salah satu aspek penting yang menunjukkan kemajuan dan kesejahteraan suatu bangsa karena pendidikan dapat melatih, membimbing dan memandu manusia terhindar atau keluar dari pembodohan dan kebodohan. Oleh karena itu perlu adanya peningkatan mutu pendidikan. Salah satu langkah nyata untuk meningkatkan mutu pendidikan yaitu dengan adanya pengembangan kurikulum dari KBK menjadi Kurikulum Tingkat Satuan Pendidikan (KTSP). Salah satu SMA yang masih menerapkan KTSP adalah SMA Negeri Kebakkramat. 
KTSP berorientasi pada hasil belajar dan menggunakan pendekatan serta metode yang bervariasi pada saat pembelajaran dan pusat sumber belajar bukan hanya guru [1]. Namun kenyataannya saat observasi pada bulan September 2017 di lapangan, pembelajaran masih didominasi oleh guru dengan metode konvensional berupa model pembelajaran ceramah, hal ini dikarenakan model ini dianggap lebih efisien waktu. Padahal kurang tepatnya guru dalam menerapkan model pembelajaran dapat mempengaruhi ketuntasan belajar siswa [2]. Seharusnya pemilihan model pembelajaran yang tepat harus disesuaikan dengan materi dan karakteristik siswanya.

Pelajaran kimia merupakan ilmu rumpun IPA yang dinggap menjadi salah satu materi yang sulit. Pelajaran kimia mencakup tiga level representasi yaitu level makroskopik, level mikroskopik, dan level simbolik. Hal ini menjadikan beberapa konsep dalam pelajaran kimia bersifat abstrak yang mempunyai katakata khusus [3]. Dalam pembelajaran kimia juga mempelajari konsep, prinsip, hukum, fakta, perhitungan dan hafalan sehingga pelajaran kimia dianggap sulit [4].

Salah satu materi kimia yang mencakup tiga level representasi ini adalah materi larutan penyangga. Materi larutan penyangga adalah salah satu materi yang tidak hanya berupa materi teori tetapi juga materi yang berupa hitungan sehingga larutan penyangga merupakan salah satu materi kimia yang dianggap sulit oleh siswa. Hal ini diperkuat dengan masih rendahnya ratarata ulangan harian materi larutan penyangga tahun pelajaran 2016/2017 di SMA kebakkramat yaitu sebesar 71,27 dari KKM sekolah yaitu 75 .

Prestasi belajar siswa pada materi larutan penyangga yang masih rendah dapat dipengaruhi oleh beberapa faktor, salah satunya berupa faktor intelegensi yaitu kemampuan matematik, hal ini dikarenakan jika dilihat dari karakteristik materi larutan penyangga yang tidak hanya berupa materi hafalan namun juga berupa materi hitungan maka siswa perlu mempunyai ketrampilan pengoperasian angka atau kemampuan matematik untuk menyelesaikan masalah pada materi larutan penyangga. Selain itu perlu model pembelajaran yang sistematis dalam menyelesaikan suatu masalah.

Oleh karena itu, maka perlu model pembelajaran yang lebih menekankan pada tahapan penyelesaian masalah serta prosesnya sesuai dengan karakteristik materi larutan penyangga yaitu model pembelajaran Thinking Aloud Pair Problem Solving (TAPPS) dan Double Loop Problem Solving (DLPS).

Model pembelajaran TAPPS terdiri dari dua orang yang bekerja secara kooperatif dimana satu orang bertugas sebagai problem solver yang bertugas sebagai pemecah masalah yang dikemukakan secara verbal agar pendengarnya dapat mengembangkan pemahamannya secara rinci untuk setiap langkah, strategi, dan asumsi pemecahan masalahnya. Sedangkan satu orang lain bertugas sebagai listener yang bertugas sebagai pendengar saat problem solver sedang menyampaikan pendapatnya dan berusaha agar problem solver agar terus menyampaikan pemikirannya serta memberikan masukan dan membimbing problem solver untuk menentukan solusi yang paling tepat [5]. Pada pembelajaran kimia, penerapan model pembelajaran TAPPS dianggap lebih efektif dibandingkan model pembelajaran konvensional. Model pembelajaran TAPPS menjadikan siswa lebih termotivasi, percaya diri dan sistematis dalam memecahkan masalah kimia [6]. Alternatif lain yang sesuai dengan materi larutan penyangga adalah model pembelajaran Double Loop Problem Solving (DLPS).

Model pembelajaran DLPS adalah model yang menekankan pada pencarian penyebab utama dari masalah tersebut sehingga menjadikan siswa menjadi lebih mandiri dan lebih kreatif [7]. Ciri utama model pembelajaran DLPS adalah mencari penyebab suatu masalah secara terus menerus sampai ditemukan tindakan yang paling tepat untuk menyelesaikannya [8].

Oleh karena itu, maka perlu dilakukan penelitian untuk mengetahui model pembelajaran yang tepat diguna- 
kan untuk meningkatkan prestasi belajar siswa pada materi larutan penyangga dengan judul "Studi Komparasi Model Pembelajaran Thinking Aloud Pair Problem Solving (TAPPS) dan Double Loop Problem Solving (DLPS) Ditinjau dari Kemampuan Matematik untuk Meningatkan Prestasi Belajar Siswa Materi Larutan Penyangga Kelas XI IPA SMA N Kebakkramat Tahun Pelajaran 2017/2018“.

\section{METODE PENELITIAN}

Penelitian ini dilakukan di SMA Negeri Kebakkramat pada kelas XI IPA Semester Genap Tahun Pelajaran 2017/201 dengan menggunakan metode eksperimen berdesain faktorial $2 \times 2$. Desain penelitian ini dapat dilihat pada Tabel 1.

Tabel 1. Rancangan Penelitan Desain Faktorial $2 \times 2$

\begin{tabular}{cccc}
\hline \multirow{2}{*}{ Kelas } & Model & \multicolumn{2}{c}{$\begin{array}{c}\text { Kemampuan } \\
\text { Matematik }\end{array}$} \\
\cline { 3 - 4 } & Pembelajaran & $\begin{array}{c}\text { Tinggi } \\
\left(\mathrm{B}_{1}\right)\end{array}$ & $\begin{array}{c}\text { Rendah } \\
\left(\mathrm{B}_{2}\right)\end{array}$ \\
\hline Eks 1 & TAPPS $\left(\mathrm{A}_{1}\right)$ & $\mathrm{A}_{1} \mathrm{~B}_{1}$ & $\mathrm{~A}_{2} \mathrm{~B}_{1}$ \\
Eks 2 & DLPS $\left(\mathrm{A}_{2}\right)$ & $\mathrm{A}_{1} \mathrm{~B}_{2}$ & $\mathrm{~A}_{1} \mathrm{~B}_{2}$ \\
\hline
\end{tabular}

Waktu penelitian ini dimulai dari bulan September 2017 sampai September 2018 dengan sampel penelitian berjumlah 72 siswa yang terbagi menjadi 2 kelas yaitu kelas XI IPA 1 sebanyak 36 siswa diberikan model pembelajaran TAPPS dan siswa kelas XI IPA 3 sebanyak 36 siswa diberikan model pembelajaran DLPS dengan mempertimbnagkan rata-rata kedua kelas yang hampir sama yang diperoleh dengan menggunakan teknik cluster random sampling

\section{HASIL DAN PEMBAHASAN}

Berdasarkan penelitian yang telah dilakukan, data yang diperoleh adalah nilai kemampuan matematik dan prestasi belajar pada materi larutan penyangga yang terdiri dari prestasi belajar ranah kognitif, ranah afektif dan ranah psikomotorik. Data dari masingmasing variabel seperti di bawah ini:

1. Data Prestasi Belajar Ranah Kognitif

Pada kelas TAPPS diperoleh ratarata sebesar 79,31 dengan nilai paling tinggi prestasi belajar ranah kognitif siswa adalah 95, nilai paling rendah 50 . Untuk kelas DLPS, diperoleh rata-rata sebesar 72,64 dengan nilai paling tinggi prestasi belajar siswa ranah kognitif adalah 85, nilai paling rendah 55 . Perbandingan distribusi frekuensinya dapat dilihat pada Tabel 2 dan Gambar 1.

Tabel 2. Distribusi Frekuensi Prestasi Kognitif Kelas TAPPS dan Kelas DLPS

\begin{tabular}{ccc}
\hline \multirow{2}{*}{ Interval } & $\begin{array}{c}\text { Kelas } \\
\text { TAPPS }\end{array}$ & $\begin{array}{c}\text { Kelas } \\
\text { DLPS }\end{array}$ \\
\cline { 2 - 3 } & Frekuensi & Frekuensi \\
\hline $50-55$ & 1 & 1 \\
$56-61$ & 0 & 1 \\
$62-67$ & 4 & 7 \\
$68-73$ & 3 & 8 \\
$74-79$ & 9 & 8 \\
$80-85$ & 9 & 10 \\
$86-91$ & 6 & 0 \\
$92-97$ & 4 & 0 \\
\hline Jumlah & 36 & 36 \\
\hline
\end{tabular}

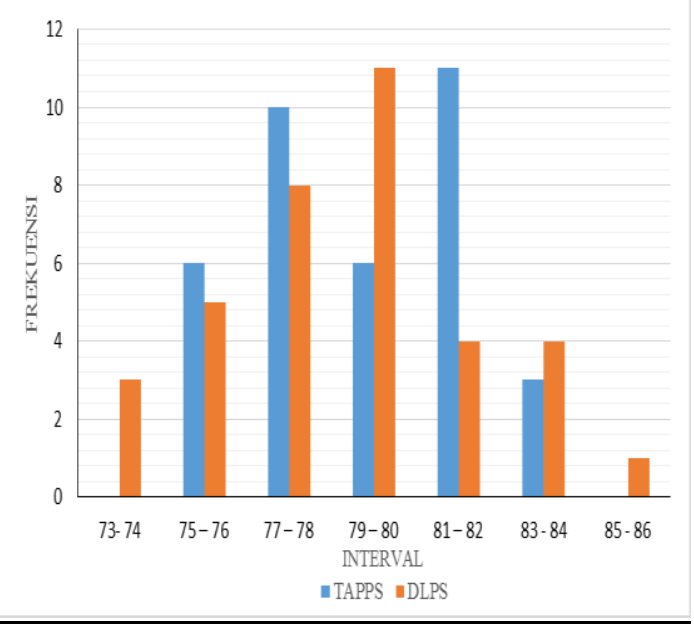




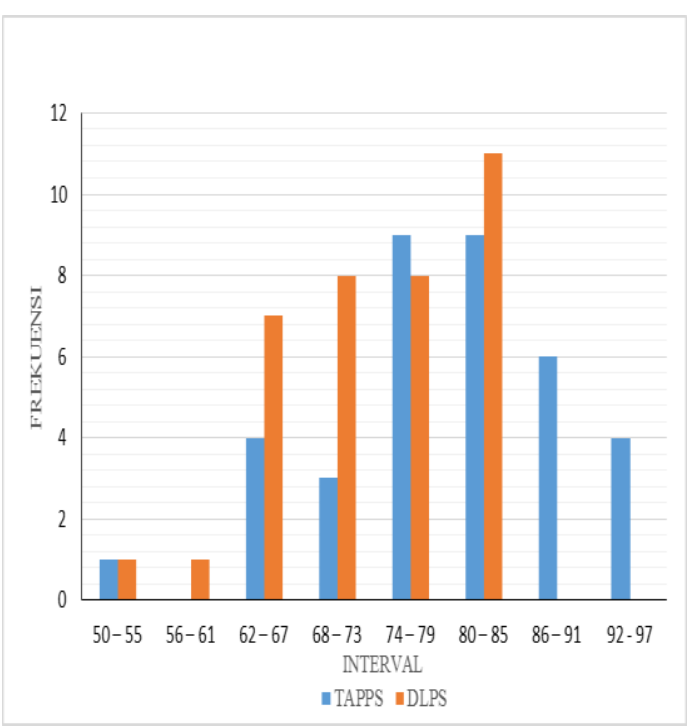

Gambar 1. Histogram Perbandingan Prestasi Kognitif Kelas TAPPS dan DLPS.

\section{Data Prestasi Belajar Ranah Afektif}

Pada kelas TAPPS mempunyai rata-rata prestasi belajar siswa sebesar 79,22 dengan nilai paling tinggi prestasi belajar ranah afektif siswa adalah 84 , dan nilai paling rendah 75 . Untuk kelas DLPS diperoleh rata-rata prestasi belajar siswa sebesar 78,75 dengan nilai paling tinggi prestasi belajar siswa ranah afektif adalah 85, nilai paling rendah 73 . Perbandingan distribusi frekuensinya dapat dilihat pada Tabel 3 dan Gambar 2.

Tabel 3. Distribusi Frekuensi Prestasi Afektif Kelas TAPPS dan DLPS

\begin{tabular}{ccc}
\hline \multirow{2}{*}{ Interval } & Kelas TAPPS & Kelas DLPS \\
\cline { 2 - 3 } & Frekuensi & Frekuensi \\
\hline $73-74$ & 0 & 3 \\
$75-76$ & 6 & 5 \\
$77-78$ & 10 & 8 \\
$79-80$ & 6 & 11 \\
$81-82$ & 11 & 4 \\
$83-84$ & 3 & 4 \\
$85-86$ & 0 & 1 \\
\hline Jumlah & 36 & 36 \\
\hline
\end{tabular}

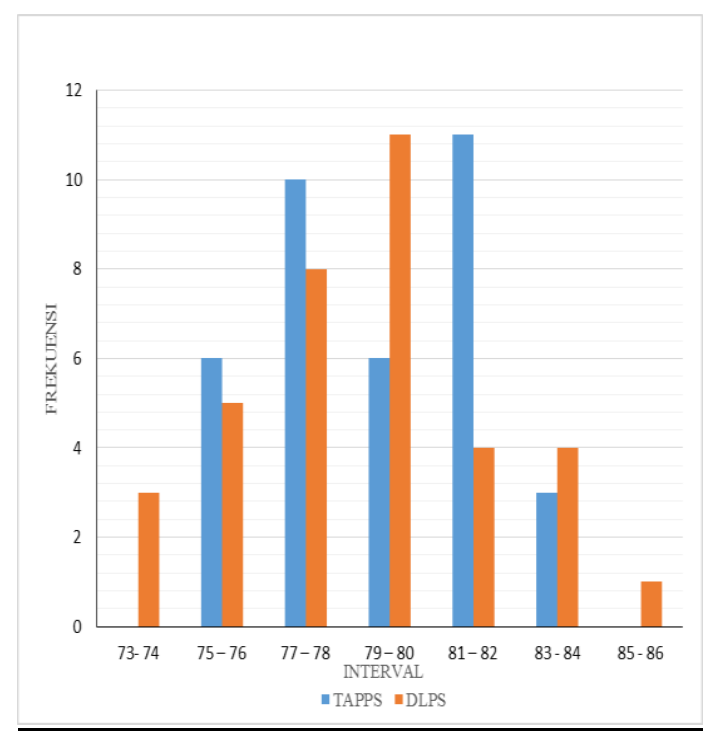

Gambar 2. Histogram Perbandingan Prestasi Afektif Kelas TAPPS dan DLPS

\section{Data Prestasi Belajar Ranah Psikomotorik}

Pada kelas TAPPS diperoleh ratarata prestasi belajar siswa ranah psikomotorik sebesar 75,59 dengan nilai paling tinggi prestasi belajar ranah psikomotorik siswa adalah 87,50 dan nilai paling rendah 60,72 . Untuk kelas DLPS diperoleh rata-rata prestasi belajar siswa sebesar 74,83 dengan nilai paling tinggi prestasi belajar siswa ranah psikomotorik adalah 80,92 dan nilai paling rendah 67,86. Perbandingan distribusi frekuensinya dapat dilihat pada Tabel 4 dan Gambar 3.

Tabel 4. Distribusi Frekuensi Prestasi Psikomotorik Kelas Eksperimen I dan Kelas Eksperimen II

\begin{tabular}{ccc}
\hline \multirow{2}{*}{ Interval } & Kelas TAPPS & Kelas DLPS \\
\cline { 2 - 3 } & Frekuensi & Frekuensi \\
\hline $60-63$ & 1 & 0 \\
$64-67$ & 2 & 0 \\
$68-72$ & 6 & 6 \\
$73-76$ & 15 & 23 \\
$77-80$ & 6 & 5 \\
$81-84$ & 5 & 2 \\
\hline $85-88$ & 1 & 0 \\
\hline Jumlah & 36 & 36 \\
\hline
\end{tabular}




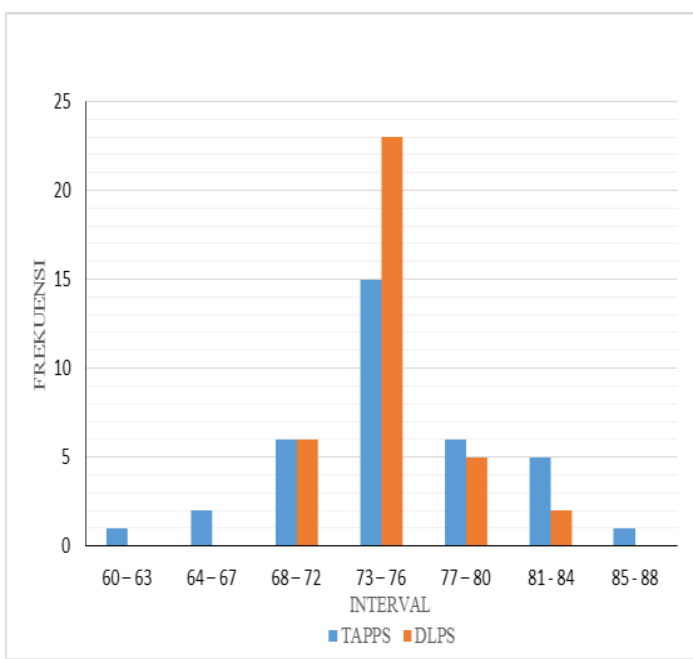

Gambar 3. Histogram Perbandingan Prestasi Psikomotorik Kelas TAPPS dan DLPS

\section{Pengujian Hipotesis}

Sebelum dilakukan uji hipotesis dilakukan maka sebelumnya perlu dilakukan uji prasyarat analisis untuk mengetahui data yang terdistribusi normal dan tidak normal serta data mempunyai variansi sama atau tidak yaitu berupa uji normalitas dan uji homogenitas. Untuk data yang tidak memenuhi prasyarat analisis yaitu berdistribusi tidak normal dan tidak homogen maka pengujian hipotesis dilakukan dengan uji statistik non parametrik Kruskal-Wallis. Berikut hasil dari uji normalitas dapat dilihat pada Tabel 5 dan hasil uji hipotesis dapat dlihat pada Tabel 6 .

Tabel 5. Hasil Pengujian Normalitas Data Nilai-Nilai Prestasi Belajar Siswa pada Masing-Masing Kelompok

\begin{tabular}{ccccccc}
\hline Uji & $\begin{array}{c}\text { Sig. } \\
\text { Terhadap } \\
\text { Prestasi } \\
\text { Ranah } \\
\text { Kognitif }\end{array}$ & Kesimpulan & $\begin{array}{c}\text { Sig. } \\
\text { Terhadap } \\
\text { Prestasi } \\
\text { Ranah } \\
\text { Afektif }\end{array}$ & Kesimpulan & $\begin{array}{c}\text { Sig. } \\
\text { Terhadap } \\
\text { Prestasi } \\
\text { Ranah } \\
\text { Psikomotor }\end{array}$ & Kesimpulan \\
\hline A & 0,127 & Normal & 0,020 & Tidak Normal & 0,000 & Tidak Normal \\
B & 0,018 & Tidak Normal & 0,200 & Normal & 0,051 & Normal \\
C & 0,000 & Tidak Normal & 0,200 & Normal & 0,001 & Tidak Normal \\
D & 0,001 & Tidak Normal & 0,049 & Tidak Normal & 0,008 & Tidak Normal \\
E & 0,034 & Tidak Normal & 0,018 & Tidak Normal & 0,010 & Tidak Normal \\
F & 0,094 & Normal & 0,039 & Tidak Normal & 0,189 & Normal \\
G & 0,000 & Tidak Normal & 0,200 & Normal & 0,175 & Normal \\
H & 0,004 & Tidak Normal & 0,200 & Normal & 0,200 & Normal \\
\hline
\end{tabular}

Tabel 6. Hasil Pengujian Hipotesis Prestasi Belajar Ranah Kognitif, Afektif dan Psikomotorik

\begin{tabular}{ccccccc}
\hline Hipotesis & $\begin{array}{c}\text { Sig } \\
\text { Terhadap } \\
\text { Prestasi } \\
\text { Ranah } \\
\text { Kognitif }\end{array}$ & Kesimpulan & $\begin{array}{c}\text { Sig } \\
\text { Terhadap } \\
\text { Prestasi } \\
\text { Ranah } \\
\text { Afektif }\end{array}$ & Kesimpulan & $\begin{array}{c}\text { Sig Terhadap } \\
\text { Prestasi } \\
\text { Ranah } \\
\text { Psikomotor }\end{array}$ & Kesimpulan \\
\hline 1 & 0,004 & Ho ditolak & 0,455 & Ho diterima & 0,448 & Ho diterima \\
2 & 0,000 & Ho ditolak & 0,711 & Ho diterima & 0,422 & Ho diterima \\
3 & 0,000 & Ho ditolak & 0,365 & Ho diterima & 0,515 & Ho diterima \\
\hline
\end{tabular}

Berdasarkan Tabel 5, data penelitian baik data prestasi belajar ranah kognitif, afektif dan psikomotorik diperoleh data berdistribusi tidak normal, sehingga pengujian hipotesis menggunakan analisis non parametrik Kruskal-Wallis dan berdasarkan Tabel 6 dapat diperoleh hasil sebagai berikut:

\section{Hipotesis Pertama}

Berdasarkan hasil statistik uji non parametrik Kruskal-Wallis menunjukkan signifikansi 0,004 terhadap prestasi belajar ranah kognitif, 0,455 terhadap prestasi belajar ranah afektif dan 0,448 terhadap prestasi belajar ranah 
psikomotorik. Jika dilihat dari hasil tersebut menunjukkan bahwa terdapat pengaruh pembelajaran kimia dengan menggunakan model pembelajaran TAPPS dan DLPS terhadap prestasi ranah kognitif namun tidak ada pengaruh terhadap prestasi ranah afektif dan psikomotorik.

Rata-rata prestasi belajar siswa ranah kognitif yang diajar dengan model pembelajaran TAPPS sebesar 79,31 dan Rata-rata prestasi belajar siswa ranah kognitif yang diajar dengan model pembelajaran DLPS sebesar 72,64. Hal ini menunjukkan siswa yang dibelajarkan dengan model TAPPS memiliki prestasi belajar ranah kognitif yang lebih baik daripada model DLPS. Perbedaan ini disebabkan karena pembelajaran dengan model TAPPS menggunakan ketrampilan sosiall yang berupa mendengarkan secara aktif, senang berbicara dan semua orang ikut berpartisipasi sehingga dapat meningkatkan prestasi belajar siswa [9]. Model TAPPS memberikan kesempatan kepada siswa untuk mengendalikan dan menyaring berbagai kemungkinan solusi permasalahan selama proses mencari dan menyelesaikan kesulitan [10]. Hal ini berarti selama proses pembelajaran TAPPS siswa akan lebih banyak berpikir, menyampaikan pendapat dan bertanya daripada melihat dan menerima informasi sehingga konsep yang diperoleh akan tertanam lebih kuat. Model pembelajaran TAPPS menjadikan siswa terlatih menghubungkan konsep dengan kerangka kerja yang sudah ada sehingga pemahaman siswa terhadap materi yang diajarkan lebih mendalam sehingga dapat meningkatkan prestasi belajar siswa [11]. Sedangkan pada pembelajaran model DLPS mempunyai langkahlangkah pembelajaran yaitu Loop satu siswa memecahkan masalah secara individu dengan cara membaca literatur untuk mengetahui penyebab masalah dan merumuskan penyelesaian masalah sementara, kemudian Loop dua yaitu berdiskusi untuk menentukan akar permasalahan dan menentukan penyelesaian akhir.

Berdasarkan uji non parametrik Kruskal-Wallis diperoleh signifikansi sebesar 0,233 lebih besar dari 0,05, maka $\mathrm{H}_{0}$ diterima. Hal ini berarti tidak ada pengaruh model pembelajaran TAPPS dan DLPS terhadap prestasi ranah afektif yang berarti bahwa prestasi belajar ranah afektif siswa pada kelas TAPPS sama baiknya dengan kelas DLPS. Hal ini didukung berdasarkan nilai rata-rata siswa pada kelas TAPPS dan DLPS yang tidak terlalu jauh berbeda yaitu kelas TAPPS 79,22 dan kelas DLPS 78,75. Penyebab tidak adanya perbedaan prestasi belajar ranah afektif karena model pembelajaran adalah faktor eksternal sedangkan aspek afektif siswa lebih dipengaruhi oleh faktor internal yang ada dalam diri siswa seperti minat, rasa ingin tahu, konsep diri dalam materi pembelajaran.

Berdasarkan uji non parametrik Kruskal-Wallis diperoleh signifikansi sebesar 0,448 lebih besar dari taraf signifikansi 0,05 , maka dapat disimpulkan $\mathrm{H}_{0}$ diterima. Hal ini menunjukkan bahwa tidak ada pengaruh model pembelajaran TAPPS dan DLPS terhadap prestasi ranah psikomotorik. Jika dilihat dari nilai rata-rata prestasi belajar ranah psikomotorik siswa yang pembelajarannya menggunakan model TAPPS dan DLPS berturut-turut yaitu 75,59 dan 74,83 . Tidak adanya perbedaan prestasi belajar ranah psikomotorik dimungkinkan karena penilaian aspek psikomotorik ini hanya dinilai berdasarkan kemampuan presentasi penyampaian hasil diskusi sehingga model pembelajaran tidak tertalu berpengaruh terhadap prestasi belajar psikomotorik siswa.

\section{Hipotesis Kedua}

Berdasarkan hasil statistik uji non parametrik Kruskal-Wallis menunjukkan nilai signifikansi 0,000 terhadap prestasi belajar ranah kognitif, 0,711 terhadap terhadap prestasi belajar ranah afektif dan 0,422 terhadap prestasi belajar ranah psikomotorik. Berdasarkan hasil tersebut menunjukkan bahwa terdapat pengaruh kemampuan matematik tinggi dan rendah terhadap prestasi belajar ranah kognitif, namun tidak berpengaruh terhadap prestasi belajar ranah afektif dan psikomotorik. 
Hal ini menunjukkan bahwa terdapat perbedaan prestasi belajar ranah kognitif antara siswa yang mempunyai kemampuan matematik tinggi dan siswa yang mempunyai kemampuan matematik rendah. Berdasarkan rata-rata prestasi belajar ranah kognitif siswa yang mempunyai kemampuan matematik tinggi sebesar 76,70 dan rendah yaitu 74,60 , maka dapat disimpulkan bahwa prestasi belajar siswa ranah kognitif lebih tinggi apabila siswa mempunyai kemampuan matematik yang tinggi jika dibandingkan dengan siswa yang mempunyai kemampuan matematik rendah sesuai dengan penelitian Merdekawati [12].

Pada prestasi belajar ranah afektif rata-rata nilai prestasi belajar ranah afektif siswa dengan kemampuan matematik tinggi 78,74 dan siswa dengan kemampuan matematik rendah 79,32 dan berdasarkan uji non parametrik menyatakan tidak ada pengaruh kemampuan matematik tinggi dan rendah terhadap prestasi belajar ranah afektif siswa. Hal ini disebabkan karena perbedaan instrumen yang digunakan untuk mengukur kemampuan matematik dengan instrumen untuk menilai prestasi sikap siswa sehingga tidak saling mempengaruhi [13].

Pada prestasi belajar ranah psikomotorik diperoleh rata-rata dari siswa dengan kemampuan matematik tinggi dan rendah berturut-turut yaitu 75,31 dan 74,56. Berdasarkan hasil uji non parametrik Kruskal-Wallis dapat disimpulkan bahwa tidak terdapat pengaruh kemampuan matematik tinggi dan rendah terhadap prestasi ranah psikomotorik. Dapat diartikan bahwa siswa yang mempunyai kemampuan matematik tinggi belum tentu mempunyai ketrampilan menyampaikan hasil diskusi yang baik pula. Hal ini disebabkan karena perbedaan instrumen untuk menilai prestasi belajar siswa ranah psikomotorik dengan instrumen yang digunakan untuk mengukur kemampuan matematik siswa.

\section{Hipotesis Ketiga}

Hipotesis ketiga mengenai interaksi antara model pembelajaran TAPPS dan DLPS dengan kemampuan matematik terhadap prestasi ranah kognitif, afektif dan psikomotorik siswa. Hasil statistik uji non parametrik KruskalWallis menunjukkan signifikansi 0,000 terhadap prestasi belajar ranah kognitif, 0,365 terhadap prestasi belajar ranah afektif dan 0,515 terhadap prestasi belajar ranah psikomotorik. Berdasarkan hasil uji menunjukkan bahwa terdapat interaksi antara model pemebalajaran TAPPS dan DLPS dengan kemampuan matematik terhadap prestasi ranah kognitif, namun tidak ada interaksi pada ranah afektif dan psikomotorik siswa. Adanya interaksi menunjukkan adanya perbedaan efek antara siswa yang diajar dengan model pembelajaran TAPPS dan DLPS ditinjau dari kemampuan matematik terhadap prestasi belajar ranah kognitif siswa. Hal ini sesuai dengan penelitian Handayani yang menyimpulkan bahwa model pembelajaran TAPPS dapat memberikan prestasi belajar yang lebih baik daripada model pembelajaran konvensional [14] serta menurut Wulandari menyatakan bahwa model pembelajaran TAPPS mampu meningkatkan nilai ketuntasan siswa [15].

Tidak adanya interaksi menunjukkan tidak ada perbedaan efek antara siswa yang diajar dengan model pembelajaran TAPPS dan DLPS ditinjau dari kemampuan matematik terhadap prestasi belajar ranah afektif siswa. Hal ini dikarenakan tidak adanya keterkaitan antara instrumen yang digunakan untuk mengukur prestasi belajar ranah afektif dengan instrumen kemampuan matematik.

Berdasarkan hasil uji non parametrik Kruskal-Wallis menunjukkan bahwa tidak ada interaksi antara model pemebalajaran TAPPS dan DLPS dengan kemampuan matematik terhadap prestasi ranah psikomotorik siswa pada materi larutan penyangga. $\mathrm{Hal}$ ini dikarenakan tidak adanya keterkaitan antara instrumen yang digunakan untuk mengukur prestasi belajar ranah psikomotorik dengan instrumen kemampuan matematik. 


\section{KESIMPULAN}

Berdasarkan hasil penelitian yang telah dilakukan dapat disimpulkan bahwa: (1) prestasi belajar ranah kognitif menunjukkan rerata model pembelajaran TAPPS lebih baik daripada model pembelajaran DLPS, namun tidak ada perbedaan prestasi belajar ranah afektif dan psikomotorik terhadap model pembelajaran, (2) siswa dengan kemampuan matematika tinggi mempunyai prestasi belajar kognitif yang lebih baik daripada siswa dengan kemampuan matematik rendah namun tidak ada perbedaan terhadap prestasi belajar ranah afektif dan psikomotorik, (3) terdapat interaksi antara model pembelajaran TAPPS dan DLPS dengan kemampuan matematik terhadap prestasi belajar ranah kognitif, namun tidak ada interaksi pada ranah afektif dan psikomotorik.

\section{UCAPAN TERIMAKASIH}

Bapak Drs. Bambang Sugeng Maladi, M.M., selaku Kepala SMA Negeri Kebakkramat yang telah mengijinkan penulis untuk mengadakan penelitian. Bapak Kasirin, S.Pd., M.Pd. selaku guru pelajaran kimia SMA Negeri Kebakkramat yang telah memberikan izin kepada penulis menggunakan kelasnya untuk penelitian.

\section{DAFTAR RUJUKAN}

[1] Hidayat, S. 2013. Pengembangan Kurikulum Baru. Bandung: PT Remaja Rosdakarya.

[2] Hamid, H. (2013). Pengembangan Sistem Pendidikan di Indonesia. Bandung: Pustaka Setia.

[3] Chang, R. (2005). Kimia Dasar: Konsep-konsep Inti (Jilid 1, Edisi 3), Terj. Muh. Abdulkadir. Jakarta: Erlangga

[4] Abduhan, R. 2016. JPK FKIP UNS. 4(4): 71-79.

[5] Lochhead, J. \& Whimbey, A. 1987. Teaching Analytical Reasoning Through Thinking Aloud Pair
Problem Solving. San Francisco: Jossey-Bass Inc., Publishers.

[6] Wah, L.L.K. 1998. Journal Teaching and Learning Institute of Education Singapore. 18(2): 89-95.

[7] Umiyaroh, F \& Handoyo, B. 2017. International Interdisciplinary Journal of Scholarly Research. 3(1): 27-35.

[8] Dooley, J. 1999. Problem Solving as A Double Loop Learning System. New York: Adaptive Learning Design.Tersedia:

http://www.bmt.smm.It/wpcontent/ uploads/2009/09/6-100209-JeffDooley-Problem-solving-as-aDouble-Loop-Learning-System.pdf

[9] Artut, P.D. 2009. International Journal of Educational Research. Cukurova University, Faculty of Education, Department of Elementary Education, 01330, Turkey, hlm. 378.

[10] Pate, M. L \& Miller, G. 2011. Journal of Agricultural Education. 52 (1): 120-131.

[11] Johnson, S. D., \& Chung, S. P. (1999). Journal of Industrial Teacher Education. 37(1): 1- 18.

[12] Merdekawati, K. 2013. Jurnal Inovasi dan Kewirausahaan. 2: 2631.

[13] Sari, D.K., Mulyani, B, \& Mulyani, S. 2014. Jurnal Pendidikan Kimia UNS. 3(1): 51-57.

[14] Wulandari, A.N. 2013. Unnes Journal of Mathematics Education. 2(3): 40- 46.

[15] Handayani. L.S. 2014. Jurnal Pendidikan Matematika UNP. 3(1): 50-55. 